\title{
STRUKTUR KALIMAT TUNGGAL BAHASA SINDANG DI KOTA LUBUKLINGGAU DAN PENGARUHNYA DALAM PEMBELAJARAN BAHASA INDONESIA
}

\author{
Noermanzah \\ STKIP-PGRI Lubuklinggau \\ E-mail: noermanzah@gmail.com
}

\begin{abstract}
ABSTRAK
Penelitian ini bertujuan memberikan pemahaman tentang struktur kalimat tunggal bahasa Sindang di Kota Lubuklinggau dan mendeskripsikan pengaruhnya dalam pembelajaran bahasa Indonesia di kota tersebut. Metode penelitian menggunakan metode deskriptif kualitatif. Hasil penelitian menunjukkan bahwa struktur kalimat tunggal bahasa Sindang di Kota Lubuklinggau berbentuk kalimat tunggal berpredikat verbal yang terdiri atas kalimat intransitif dan kalimat tungggal ekatransitif; kalimat tunggal berpredikat adjektival, kalimat tunggal berpredikat nominal, kalimat tunggal berpredikat numeral, kalimat tunggal berpredikat preposisional, dan kalimat tunggal berpredikat adverbial. Sebagian besar kalimat tunggal berpredikat verbal pada bahasa Sindang lebih banyak digunakan oleh masyarakat penuturnya yaitu kalimat intransitif dengan 62 kalimat atau 79,5\%. Kalimat bahasa Sindang ditinjau dari segi fungsi untuk jenis kalimat intransitif memiliki struktur fungsi: 1) S,P; 2) K,S,P; 3) S,P,Vokatif; 4) $\mathrm{S}, \mathrm{P}, \mathrm{K}$; 5) P,K; 6) P,S; 7) P; 8) S,P,S, dan 9) S,P,Pel. Jenis kalimat ekatransitif memiliki struktur fungsi: 1) K,S,P,O,K; 2) S,P,O,Vokatif; 3) P,O,K; 4) P,O; 5) P,O,K,S; 6) S,P,O; dan 7) $\mathrm{P}, \mathrm{O}, \mathrm{S}$. Kalimat tunggal berpredikat adjektival memiliki struktur fungsi yaitu berstruktur K,S,P dan P,S. Kalimat tunggal berpredikat nominal memiliki struktur fungsi S,P. Kalimat tunggal berpredikat numeral memiliki struktur fungsi P,S dan S,P. Kalimat tunggal berpredikat frase preposisional memiliki struktur fungsi S,P,Vokatif. Kemudian, kalimat tunggal berpredikat adverbia memiliki struktur fungsi S,P. Struktur kalimat tunggal bahasa Sindang memberikan pengaruh positif terhadap pembelajaran bahasa Indonesia penutur asli bahasa tersebut.
\end{abstract}

Kata kunci: struktur kalimat tunggal, bahasa Sindang, Lubuklinggau

\section{THE SINGLE SENTENCE STRUCTURE OF SINDANG LANGUAGE IN LUBUKLINGGAU CITY AND ITS INFLUENCE IN INDONESIAN LANGUAGE LEARNING}

\footnotetext{
ABSTRACT

The objective of this research is to give the understanding about the simple sentence structure Sindang Language ini Lubuklinggau and describe the effect in Indonesian 
language learning process. This research used descriptive qualitative method. The result of this research shows that the simple sentence structure of Bahasa Sindang in Lubuklinggau in the form of verbal-verbed simple sentence which consists of intransitive sentence and single-transitive sentence; adjectival-verbed simple sentence, nominal-verbed simple sentence, numeral-verbed simple sentence, preposisional-verbed simple sentence, and adverbial-verbed simple sentence. Majority of the data finding is the verbal-verbed simple sentence on Sindang language and it is more used by the people who use Sindang language. Intransitive sentence has 62 sentences or $79.5 \%$. Sentence of Sindang Language seen from the aspect of function for the type of intransitive sentence has the function structure: 1) S,P; 2) K,S,P; 3) S,P,Vokatif; 4) $\mathrm{S}, \mathrm{P}, \mathrm{K}$; 5) $\mathrm{P}, \mathrm{K}$; 6) $\mathrm{P}, \mathrm{S}$; 7) $\mathrm{P}$; 8) S,P,S, and 9) S,P,Pel. The type of single-transitive sentence has the structure function: 1) K,S,P,O,K; 2) S,P,O,Vokatif; 3) P,O,K; 4) P,O; 5) $\mathrm{P}, \mathrm{O}, \mathrm{K}, \mathrm{S}$; 6) $\mathrm{S}, \mathrm{P}, \mathrm{O}$; dan 7) $\mathrm{P}, \mathrm{O}, \mathrm{S}$. Adjectival-verbed sentence has the structure function of structure K,S,P and P,S. Nominal-verbed simple sentence has the function structure S,P. Numeral-verbed simple sentence has the function structure P,S and S,P. Prepositional Frase-verbed simple sentence has the function structure S,P,Vocative. Then, adverbial-verbed simple sentence has the function structure S,P. The single sentence structure of the Sindang language positively influences the learning of the native speakers of the language.

Keywords: simple sentence structure, Sindang language, Lubuklinggau

\section{PENDAHULUAN}

Bahasa Sindang merupakan salah satu bahasa daerah yang digunakan dalam wilayah yang cukup luas, yaitu kurang lebih $360 \mathrm{Km}^{2}$. Beberapa wilayah yang terdapat masyarakat penutur bahasa Sindang yaitu Kabupaten Musi Rawas termasuk Kota Lubuklinggau, Kabupaten Rejang Lebong, dan Kabupaten Lahat (Suwandi, 1996). Kemudian, berdasarkan nama wilayah marga-marga tiga aliran sungai besar, maka nama bahasa Sindang mulanya berasal dari tiga marga tersebut, yaitu Sindang Kelingi, Sindang Beliti, dan Sindang Lakitan.Selain digunakan sebagai alat komunikasi utama dalam kehidupan sehari-hari, bahasa Sindang juga digunakan dalam berbagai aktivitas, misalnya dalam upacara perkawinan, upacara adat, dan proses jual beli di pasar tradisional. Dengan demikian, di daerah-daerah itu bahasa Sindang memiliki fungsi yang cukup penting. Mengingat fungsinya yang cukup penting itu, wajar bila bahasa Sindang perlu terus dibina dan dikembangkan dengan usaha pembinaan dimaksudkan 
agar masyarakat penutur mampu mengggunakan bahasa Sindang dengan baik dan benar.

Bahasa Sindang masih tetap memegang peranan dan mempunyai kedudukan yang penting dalam masyarakat penuturnya. Oleh karena itu, bahasa Sindang perlu mendapat perhatian, pemeliharaan, dan pembinaan terutama dalam usaha pembinaan dan pengembangan bahasa Indonesia pada umumnya dan pengembangan teori linguistik pada khususnya. Pada penjelasan UUD 1945 pasal 36 dinyatakan bahwa bahasa-bahasa daerah yang masih dipakai sebagai alat penghubung yang hidup dan dibina oleh negara karena bahasa-bahasa itu bagian dari kebudayaan Indonesia yang hidup.

Dari uraian di atas, maka penelitian yang esensial dan sungguh-sungguh terhadap bahasa daerah di nusantara ini sangat besar manfaatnya. Para ahli yang berkecimpung dalam dunia kebahasaan yang berusaha meneliti bahasa daerah di nusantara ini akan membawa manfaat, termasuk di dalamnya bahasa-bahasa yangada di Sumatera Selatan dan Bengkulu pada umumnya dan bentuk kalimat tunggal bahasa Sindang pada khususnya yang menjadi kajian dalam penelitian ini.

Badudu (1998) mengemukakan bahwa "bahasa itu terus menerus berubah, maka gejala-gejala kebahasaan yang bersifat lisan yang sekarang ada apabila tidak didokumentasikan kita akan kehilangan jejak salah satu kebudayaan itu". Untuk itu pentingnya mengkaji struktur kalimat tunggal bahasa Sindang khususnya yang digunakan masyarakat penutur di Wilayah Kota Lubuklinggau. Hasil penelitian ini bertujuan untuk mendapatkan informasi yang lengkap dan mendetail tentang struktur kalimat tunggal bahasa Sindang.

Dalam penelitian ini, masalah yang akan dijawab yaitu "Bagaimanakah struktur kalimat tunggal bahasa Sindang di Kota Lubuklinggau? Dalam penelitian ini hanya 
mengkaji bahasa Sindang yang digunakan oleh masyarakat penutur dalam konteks keluarga dan bertetangga di Kelurahan Air Kuti Kecamatan Lubuklinggau Timur I dan Kayu ArahKecamatan Lubuklinggau Barat, Kota Lubuklinggau Provinsi Sumatera Selatan. Kemudian, jenis bahasa yang diteliti adalah bahasa lisan sehari-hari masyarakat Kota Lubuklinggau.Penelitian ini bertujuan memberikan pemahaman tentang struktur kalimat tunggal bahasa Sindang di Kota Lubuklinggau.

Sebagai unsur pembangun wacana, kalimat memiliki beberapa bentuk, yaitu kailmat berdasarkan bentuk dan kalimat berdasarkan makna. Kalimat berdasarkan bentuk terdiri atas: kalimat tunggal dan kalimat majemuk, sedangkan berdasarkan maknanya terdiri atas: kalimat berita, kalimat tanya, kalimat kalimat seru, dan kalimat empatik (Muslich, 2010). Dalam teori ini akan dijelaskan khusus jenis kalimat tunggal.

Kalimat tunggal dikemukakan oleh Putrayasa (2007) sebagai kalimat yang terdiri atas satu klausa atau satu konstituen SP. Dengan demikian, unsur inti kalimat tunggal menurut Putrayasa adalah subjek dan predikat. Hal yang senada dijelaskan oleh Parera (2009) bahwa kalimat tunggal merupakan kalimat yang terdiri dari satu klausa yang kedudukannya sebagai dasar berdirinya kalimat.

Kemudian, menurut Ramlan (2005) kalimat tunggal dijelaskan dengan kalimat yang terdiri dari satu kalusa. Klausa tersebut sebagai satuan gramatik yang terdiri dari subjek dan predikat, dapat disertai objek, pelengkap, dan keterangan. Dengan demikian, klausa ialah S P (O) (PEL) (KET). Tanda kurung menandakan bahwa apa yang terletak dalam kurung itu bersifat manasuka atau boleh ada, boleh tidak (Dardjowidjojo, 2010).

Chaer (2007) juga memberikan pendapat tentang kalimat tunggal sebagai kalimat yang klausanya terdiri dari satu. Berikut contoh kalimat yang dijelaskan Chaer: 
Mereka pintar. Contoh kalimat tersebut terdiri dari S dan P. Posisi subjek adalah Mereka (kata nomina/benda) dan predikat adalah kata pintar (kata adjektiva/sifat).

Wijana (2011) mengatakan bahwa kalimat tunggal adalah kalimat yang terdiri atas satu klausa. Subjek dan predikat adalah unsur inti klausa. Verhaar (2010) mengatakan bahwa dalam hubungan analisis fungsi ada empat terminologi analisis fungsi yang berbeda. Pertama, kalimat dibagi atas subjek dan predikat. Kedua, kalimat dibagi atas subjek, predikat, dan keterangan. Keterangan dibagi lagi atas objek dan keterangan waktu, keterangan tempat, dan lain-lain. Ketiga, kalimat dibagi atas subjek, predikat, dan pelengkap. Pelengkap dibagi atas objek dan keterangan. Selanjutnya keterangan dibagi atas keterangan waktu, keterangan tempat, dan lain-lain. Keempat, kalimat dibagi atas subjek, predikat, objek, dan keterangan. Berikutnya keterangan dibagi atas keterangan waktu, keterangan tempat, dan lain-lain, sedangkan analisis kalimat berdasarkan kategori unsur-unsurnya adalah menentukan termasuk kategori apakah suatu unsur dalam suatu kalimat. Analisis kategori adalah analisis terhadap jenis kata atau kelas kata unsur-unsur pengisi fungsi tertentu dalam sebuah kalimat.

Dari beberapa pendapat di atas, dapat disimpulkan bahwa kalimat tunggal adalah kalimat yang hanya terdiri dari subjek dan predikat atau satu kalusa yang boleh dilengkapi unsur objek, pelengkap, dan keterangan.

Putrayasa (2007) menjelaskan beberapa struktur kalimat tunggal sebagai berikut: kalimat berpredikat verbal, kalimat berpredikat adjektival, kalimat berpredikat nominal, kalimat berpredikat numeral, kalimat berpredikat frase preposisional. Putrayasa (2007) lebih lanjutmengemukakan bahwa dalam kalimat tunggal tidak hanya terdiri dari subjek dan predikat, tetapi mengalalami perluasan. Perluasan kalimat tunggal itu dapat dilakukan dengan penambahan unsur keterangan, unsur vokatif, dan konstruksi aposisi. 
Penambahan unsur keterangan dapat berupa keterangan waktu, tempat, tujuan, cara, penyerta, alat, perbandingan, sebab, kesalingan, akibat, alas an, asal, kualitas, kuantitas, modalitas, perwatasan (batas-batas predikat, objek, dan syarat. Nomina vokatif merupakan konstituen tambahan dalam ujaran berupa nomina atau frase nominal yang menyatakan orang yang disapa. Unsur vokatif itu bersifat manasuka, dan letaknya dapat di awal, tengah, atau di akhir kalimat.

Nomina vokatif itu tidak merupakan bagian integral suatu kalimat dan hal itu terlihat dalam intonasi. Unsur vokatif dipisahkan dalam intonasi dengan bagian kalimat lain dengan membentuk satuan tona sendiri atau menjadi ekor satuan tona. Ciri intonasi yang paling lazim bagi unsur vokatif adalah intonasi naik. Vokatif awal sering juga mempunyai intonasi turun-naik. Fungsi nomina vokatif adalah meminta perhatian orang yang disapa, terutama jika ada pendengar lain. Bentuk vokatif yang digunakan juga mengisyaratkan sikap pembicara terhadap si pendengar.

Aposisi merupakan penjelasan atau keterangan pengganti yang menggantikan unsur yang ada di depannya, baik unsure S, P, O, Pel, maupun K. Oleh karena itu, aposisi disebut juga keterangan pengganti. Aposisi dapat berupa kelompok kata, dan dapat juga berupa kalimat, dengan yang sebagai subjeknya. Dua unsur kalimat tersebut beraposisi jika kedua unsur itu sederajat dan mempunyai acuan yang sama atau paling tidak salah satu mencakup acuan unsur lainnya.

Kemudian, dalam sebuah kalimat, kata bisa dibedakan dari segi kategori berupa nomina, verba, adjektiva, dan adverbial. Sedangkan dari segi frasenya dapat berupa frase nominal, verbal, adjectival, dan preposisional. Dalam kalimat juga kita mengenal struktur kalimat berwujud fungsi. Suatu kalimat, fungsi berbeda dari kategori yang mengacu ke makna kata, dan lebih mengacu ke tugas unsur dalam kalimat, yaitu fungsi 
subjek (S), predikat (P), objek (O), pelengkap (Pel.), dan keterangan (K) (Muslich, 2010:126).

Lebih lanjut Muslich (2010) menjelaskan bahwa bentuk kalimat tunggal juga kemungkinan dapat berupa kalimat tunggal berpredikat adverbia. Adverbia merupakan semua kata yang maknanya menerangkan verba, adjektiva, numeralalia, nomina predikatif, atau kalimat. Akan tetapi, dalam kedudukannya dalam predikat, adverbial ini jenisnya berfungsi sebagai kata keterangan atau waktu. Misalnya, pada kalimat:Tagihannya bulanan. Dalam kalimat tersebut kata bulanan menunjukkan kata adverbia yang berfungsi menerangkan waktu tagihan akan dilakukan.

Kemudian, bahasa Sindang yang oleh masyarakat Lubuklinggau terkenal dengan sebutan bahasa $\mathrm{Cul}$ merupakan bahasa yang digunakan oleh masyarakat penutur yang berada di sebagian kecil Provinsi Sumatera Selatan dan Provinsi Bengkulu. Menurut Suwandi (1996) bahasa Sindang merupakan salah satu bahasa daerah yang digunakan dalam wilayah yang cukup luas, yaitu kurang lebih $360 \mathrm{Km}^{2}$. Beberapa wilayah yang terdapat masyarakat penutur bahasa Sindang yaitu Kabupaten Musi Rawas termasuk Kota Lubuklinggau, Kabupaten Rejang Lebong, dan Kabupaten Lahat (Suwandi, 1996). Kemudian, berdasarkan nama wilayah marga-marga tiga aliran sungai besar, maka nama bahasa Sindang mulanya berasal dari tiga marga tersebut, yaitu Sindang Kelingi, Sindang Beliti, dan Sindang Lakitan.

Suwandi (1996) wilayah penutur bahasa Sindang berdasarkan peta wilayah terdiri dari 69 daerah yang memiliki ciri khas dalam pengucapan kata, yaitu Lubuklinggau (ulu dan ilir), Lubuk Aman dan Lubuk Tanjung, Kayu Ara, Lubuk Durian, Sumber Agung, Petanang, Batu Pepe, Durian Rampak, Tanjung Raya, Selangit, Taba Tengah, Taba Renah, Taba Ginde, Batu Gane, Muara Nilau, Bukit Pinang, Lubuk 
Ngin, Durian Terung, Durian Sebatang, Terawas Baru, Terawas Lama, Babat Terawas, Pasenan, Taba Pingin, Air Kati, Jukung, Tanah Periuk Sp., Tanah Periuk D1, Lubuk Kupang, Pedang, Muara Beliti, Muara Kati, Batu Bandung, Rantau Pauh, Rantau Bingin, Suro (termasuk Remayu dan Lubuk Rumbai), Semambang, Lubuk Besar, Jayaloka, Ngestiboga, Kebur, Rantau Serik, Tanjung Raya, Tanjung Sanai, Padang Ulak Tanding, Geragung (Guru Angung), Taba Remanik, Merantau, Periang, Balai Buntar, Lubuk Belimbing 1, Lubuk Belimbing 2, Durian Mas, Lubuk Mumpo, Derati, Kota Padang, Kepala Curup, Apur, Tanjung Pangeran, Jabing, Pelalo, Belitar, Beringin III, Muara Saling, Dusun Sawah, Taba Kebon, Tanjung Ning Lama, Tanjung Ning Baru, dan Tebing Tinggi.

Bahasa Sindang bagi masyarakat Provinsi Bengkulu disebut dengan bahasa Lembak karena dimiliki oleh suku Lembak yang berada di wilayah kota bengkulu, Bengkulu Utara, Kabupaten Bengkulu Tengah,Kabupaten Rejang Lebong, dan Kabupaten Kepahiang. Suku Lembak di kabupaten Rejang Lebong bermukim di kecamatan Padang Ulak Tanding, Sindang Kelingi, dan Kota Padang. Di kabupaten Kepahiang, suku Lembak mendiami desa Suro Lembak (Wikipedia, http://id.wikipedia.org/wiki/Suku_Lembak). Kemudian, secara umum suku Lembak tidak jauh berbeda dengan masyarakat Melayu pada umumnya, namun dalam beberapa hal terdapat perbedaan.

Jika ditinjau dari segi bahasanya, suku Lembak dengan Melayu Bengkulu (pesisir) terdapat perbedaan dari segi pengucapan kata-katanya, Melayu Bengkulu kata-katanya banyak diakhiri dengan huruf 'o' sedangkan suku Lembak banyak menggunakan huruf 'e', selain itu ada kosakata yang berbeda.Selain digunakan sebagai alat komunikasi utama dalam kehidupan sehari-hari, bahasa Sindang juga 
digunakan dalam berbagai aktivitas, misalnya dalam upacara perkawinan, upacara adat, pemerintahan, dan proses jual beli di pasar tradisional.

\section{METODE}

Penelitian ini meenggunakan penelitan deskriptif kualitatif, yaitu penelitian yang bertujuan menggambarkan sifat, keadaan, dan gejala (fenomena) kebahasaan bahasa Sindang (BS) pada suatu waktu saat penelitian ini dilakukan (sinkronis). Metode yang digunakan dalam mengumpul data lapangan ialah metode simak.

Data dalam penelitian ini adalah seluruh struktur kalimat tunggal bahasa Sindang diKelurahan Kelurahan Air Kuti Kecamatan Lubuklinggau Timur I dan Kayu Arah Kecamatan Lubuklinggau Barat, Kota Lubuklinggau Provinsi Sumatera Selatan. Sumber data berupa informan sebagai pengguna bahasa Sindang dari perwakilan masyarakat asli pengguna bahasa Sindang ada di Kelurahan Air Kuti Kecamatan Lubuklinggau Timur I dan Kayu Arah Kecamatan Lubuklinggau Barat.

Subjek penelitian adalah orang atau penutur asli bahasa Sindang yang terdiri dari satu keluarga dari Kelurahan Air Kuti, satu keluarga dari Taba Pingin Kota Lubuklinggau.Kriteria informan juga yang sudah penutur asli bahasa Sindang yang sehat jasmani dan rohani khusunya jelas dalam bertutur kata serta berpendidikan minimal sekolah dasar.

Teknik yang diterapkan ialah teknik sadap,teknik rekam,dan teknik catat. Teknik sadap dilakukan dengan cara menyadap penggunaan bahasa lisan penutur/informan, baik berencana maupun serta merta (Sudaryanto, 1993). Kemudian, teknik catat menurut Kesuma (2007) adalah teknik menjaring data tertulis dengan mencatat hasil penyadapan pada kartu data. Kartu data dapat berupa kertas HVS, manila, dan buffalo. 
Data penelitian dianalisis berdasarkan pendekatan linguistik struktural. Pendekatan linguistik digunakan untuk mengkaji struktur kalimat tunggal bahasa Sindang, dan menentukan pola atau struktur kalimat tunggal bahasa Sindang. Oleh karena itu, metode yang digunakan adalah metode analisis fungsi unsur kalimat. Teknik yang digunakan adalah teknik analisis kriteria fungsi (Verhaar, 1997).

Dalam penelitian ini instrumen utama adalah peneliti. Peneliti dalam hal ini berperan sebagai pengamat. Peneliti dibantu dengan instrumen berupa taperecorder, buku catatan berupa kartu data.Teknik analisis data dalam penelitian ini menggunakan model induktif. Model induktif yang digunakan berdasarkan pendapat Djajasudarma (2010) dengan langkah-langkah sebagai berikut:pengamatan data dan pengumpulan data, menyusun struktur data, perumusan hipotesis, dan pengujian hipotesis, Teori tentang bahasa baru dianggap sahih (valid) bila hasil itu dapat diuji oleh peneliti lain dengan hasil yang sama.

Kemudian,beberapa cara yang digunakan untuk menguji keabsahan data, sebagai berikut: (1) kredibilitas, dalam penelitian ini, kredibilitas dilakukan dengan cara perpanjangan pengamatan pada subjek penelitian, ketekunan penelitian, diskusi teman sejawat, dan membercheck dengan harapan hasil penelitian dapat dipercaya keilmiahannya. (2) Transferabilitas, dalam penelitian ini transferabilitas dilakukan dengan penyajian data tentang struktur kalimat tunggal bahasa Sindang di wilayah Kota Lubuklinggau secara rinci, jelas, sistematis, masuk akal, dan objektif sehingga dapat menambah tingkat validitas eksternalnya. (3) Dependabilitas, dalam peneitian ini dilakukan dengan mengaudit keseluruhan proses penelitian oleh seorang auditor yang independen. Audit dilakukan dimulai ketika menentukan masalah/fokus, memasuki lapangan, menentukan sumber data, melakukan analisis data, melakukan uji keabsahan 
data, sampai membuat kesimpulan harus dapat ditunjukkan oleh peneliti. (4) Konfirmabilitasatau objektivitas, dalam penelitian ini konfirmabilitas dilakukan cara mendokumentasikan seluruh data dan hasil kegiatan analisis data penelitian ke dalam bagian lampiran sehingga hasil penelitian benar-benar objektif dan ilmiah.

\section{HASIL DAN PEMBAHASAN}

Hasil penelitian mengenai struktur kalimat tunggal bahasa Sindang di Kota Lubuklinggau khususnya pada bentuk bahasa lisan menunjukkan bahwa struktur yang tidak berbeda jauh dari kalimat bahasa Indonesia. Struktur kalimat tunggal bahasa Sindang di Kota Lubuklinggau terdiri atas beberapa bentuk, di antaranya kalimat tunggal berpredikat verbal, berpredikat adjektival, berpredikat nominal, berpredikat nominal, berpredikat numeral, berpredikat frase preposisional, dan juga memiliki keunikan yaitu memiliki struktur berpredikat verbal adverbia (kata keterangan).

Kalimat tunggal berpredikat verbal dari hasil temuan dalam data percakapan wacana lisan bahasa Sindang di Kota Lubuklinggau terbagi atas kalimat intransitif dan ekatransitif. Untuk jenis kalimat intransitif berjumlah 45 kalimat dan apabila dipersentasekan menjadi 57,7\% dengan struktur kalimat berdasarkan fungsi, yaitu:1). S,P; 2). K,S,P; 3). S,P,Vokatif; 4). S,P,K; 5). P,K; 6). P,S; 7). P; dan 8). S,P,S, dan 9). S,P,Pel. Sedangkan jenis kalimat ekatransitif berjumlah 17 kalimat atau $22 \%$ dari jumlah seluruh data yang dianalisis dengan struktur kalimat berdasarkan fungsi, antara lain: 1). K,S,P,O,K; 2). S,P,O,Vokatif; 3). P,O,K; 4). P,O; 5). P,O,K,S; 6). S,P,O; dan 7). P,O,S. Untuk sementara, jenis kalimat dwitransitif dan kalimat semitransitif belum ditemukan dalam penelitian ini.

Kalimat tunggal berpredikat adjektivaldari data percakapan wacana lisan bahasa

Sindang di Kota Lubuklinggau ditemukan 4 kalimat atau 5,1 \% dari seluruh data yang 
diteliti. Dalam kalimat tunggal berpredikat adjektival apabila ditinjau dari struktur kalimat berdasarkan fungsi, ditemukan dua bentuk struktur fungsi yaitu berstruktur $\mathrm{K}, \mathrm{S}, \mathrm{P}$ dan $\mathrm{P}, \mathrm{S}$.

Kalimat tunggal berpredikat nominal dari data percakapan wacana lisan bahasa Sindang di Kota Lubuklinggau hanya ditemukan 1 kalimat atau 1,3\% dari seluruh data yang diteliti. Sedangkan kalimat tunggal berpredikat nominal dari data penelitian dilihat dari struktur kalimat berdasarkan fungsi memiliki struktur fungsi S,P.

Kalimat tunggal berpredikat numeral dari data percakapan wacana lisan bahasa Sindang di Kota Lubuklinggau ditemukan 8 kalimat atau 10\% dari seluruh data yang diteliti. Kemudian, kalimat tunggal berpredikat numeral dari data penelitian ditinjau dari struktur kalimat berdasarkan fungsi memiliki struktur fungsi P,S dan S,P.

Kalimat tunggal berpredikat frase preposisional dari data percakapan wacana lisan bahasa Sindang di Kota Lubuklinggau hanya ditemukan 1 kalimat atau 1,3\% dari seluruh data yang diteliti. Kemudian, kalimat tunggal berpredikat frase preposisional dari data penelitian ditinjau dari struktur kalimat berdasarkan fungsi memiliki struktur fungsi S,P,Vokatif.

Kemudian, untuk kalimat tunggal berpredikat adverbia dari data percakapan wacana lisan bahasa Sindang di Kota Lubuklinggau hanya ditemukan 2 kalimat atau 2,6\% dari seluruh data yang diteliti. Kemudian, kalimat tunggal berpredikat adverbia dari data penelitian ditinjau dari struktur kalimat berdasarkan fungsi memiliki struktur fungsi S,P.

Bahasa Sindang di Kota Lubuklinggau khususnya dalam percakapan sehariharimemiliki kekhasan dari bentuk kalimat tunggalnya, di antaranya berbentuk kalimat tunggal berpredikat verbal, berpredikat adjektival, berpredikat nominal, berpredikat 
nominal, berpredikat numeral, berpredikat frase preposisional, dan juga memiliki keunikan khusus yaitu memiliki struktur berpredikat verbal adverbia. Dengan mengungkapkan kalimat tunggal yang bervariasi menunjukkan bahwa bahasa benarbenar unik dan mampu mewakili ungkapan pikiran dan perasaan penuturnya lewat variasi susunan predikat dan unsur sebelum dan sesudahnya yang membentuk kalimat sehingga terjadi interaksi antara penutur dan mitra tutur. Hal ini sesuai dengan fungsi bahasa yang digunakan oleh anggota suatu masyarakat bahasa untuk berkomunikasi dan berinteraksi antar sesamanya, berlandaskan pada budaya yang mereka miliki bersama.

Bentuk kalimat tunggal bahasa Sindang sebagian besar berbentuk kalimat tunggal berpredikat verbal dengan jenis kalimat intransitif dan ekatransitif. Kemudian, dari jenis kalimat tunggal berpredikat verbal didominasi pada penggunaan kalimat intransitif dengan jumlah kalimat sebanyak 45 kalimat atau $57,7 \%$ dari seluruh data percakapan. Sedangkan jenis kalimat ekatransitif terdapat 17 kalimat atau $22 \%$ dari data percakapan. Hal ini menunjukkan bahwa dalam wacana lisan kalimat tunggal berpredikat verbal pada bahasa Sindang lebih banyak digunakan oleh masyarakat penuturnya yaitu kalimat intransitif dengan 62 kalimat atau 79,5\%. Kalimat intransitif ini lebih banyak digunakan karena dalam wacana lisan pada aspek S,Pel., dan K dapat digantikan dengan unsur lain seperti suasana, kinesik, waktu, dan konteks komunikasi lainnya. Untuk itu, kalimat intransitif dengan pola S,P lebih banyak, bahkan berbentuk kalimat minor yang unsur fungsi S-nya dilesapkan yang hanya memiliki unsur fungsi $\mathrm{P}$ juga sering digunakan dalam suatu percakapan lisan.

Kalimat intransitif pada bahasa Sindang memiliki pola struktur fungsi 1). S,P; 2). K,S,P; 3). S,P,Vokatif; 4). S,P,K; 5). P,K; 6). P,S; 7). P; dan 8). S,P,S. Dari pola struktur kalimat intransitif terbanyak yaitu berpola S,P. Hal ini sesuai dengan pengertian 
dari unsur kalimat intransitif yang wajib memiliki unsur $\mathrm{S}$ dan $\mathrm{P}$ dan tidak memiliki atau tidak membutuhkan kehadiran objek. Berikut contoh kalimat dengan pola struktur fungsi S,P pada data KTP-79.

Kapan nganak latean gi?

$\mathrm{S} \quad \mathrm{P}$

(Kapan kamu ingin latihan lagi?)

Dari contoh data KTP-79 dapat dijelaskan bahwa kalimat tanya yang ditunjukkan kata tanya kapan dikuti oleh unsur fungsi S nga (kamu) berupa kata benda (nomina) yang dilanjutkan dengan unsur fungsi $\mathrm{P}$ nak latean gi (ingin latihan lagi) berupa kata kerja (verba) yang menyatakan makna perbuatan, pekerjaan, atau tindakan akan melaksanakan latiahan bola voli.

Struktur kalimat intransitif dengan pola struktur fungsi K,S,P juga terdapat dalam wacana lisan bahasa Sindang. Berikut contoh kalimatnya pada data KTP-37.

Pokok'a jam setengah 4 tu lahcol gi petaninak begawe.

$\begin{array}{llll}\mathrm{K} & \mathrm{S} & \mathrm{P}\end{array}$

(Pokoknya jam setengah 4 sudah tidak ada lagi petani yang berkerja.)

Dari data KTP-37 di atas dapat kita lihat bahwa kalimat tersebut memiliki pola struktur fungsi K,S,P. Unsur fungsi m berupa adverbia (kata keterangan), S berupa kata nomina, dan P berupa kata kerja. Dari pola kalimat intransitif ini, menunjukkan bahwa unsur K dapat diposisikan di awal kalimat bukan hanya setelah P. Hal yang terpenting dalam kalimat intransitif adalah kalimat yang tidak membutuhkan unsur fungsi objek, walaupun kalimat tersebut masih belum jelas sasarannya apa. Misalnya dalam kalimat KTP-37, petani tersebut bekerja apa? Meskipun secara umum petani mengerjakan tanah dan melakukan proses menanam, tetapi belum jelas apa yang dikerjakannya.

Struktur kalimat intransitif dengan pola struktur fungsi S,P,Vokatif juga terdapat dalam wacana lisan bahasa Sindang. Untuk lebih jelasnya dapat dilihat dari salah satu kalimat dari data KTP-38 berikut. 


\section{RiskatinggalLi ye? (Riska ditinggal Li y a ? \\ S P Vokatif}

Dari contoh kalimat intransitif di atas, menunjukkan bahwa kalimat bahasa Sindang dapat berbentuk kalimat intransitif dengan pola struktur fungsi S,P,Vokatif. Unsur vokatif dalam kaimat intransitif tersebut sebagai unsur tambahan sebagian bagian integral kalimat yang berfungsi untuk memberi sikap penekanan kepada pendengar perihal penegasan tentang suatu informasi yang ditanyakan. Unsur vokatif dalam kalimat intransitif ini berbentuk nomina dan uniknya vokatif ini ditambah unsur ya di depan vokatif. Hal ini sesuai dengan pendapat Putrayasa (2007:41) bahwa nomina vokatif itu tidak merupakan bagian integral suatu kalimat dan hal itu terlihat dalam intonasi. Unsur vokatif dipisahkan dalam intonasi dengan bagian kalimat lain dengan membentuk satuan tona sendiri atau menjadi ekor satuan tona. Ciri intonasi yang paling lazim bagi unsur vokatif adalah intonasi naik. Vokatif awal sering juga mempunyai intonasi turun-naik. Fungsi nomina vokatif adalah meminta perhatian orang yang disapa, terutama jika ada pendengar lain atau dapat juga digunakan juga mengisyaratkan sikap pembicara terhadap si pendengar.

Struktur kalimat intransitif dengan pola struktur fungsi S,P,K juga terdapat dalam wacana lisan bahasa Sindang. Struktur kalimat dengan pola ini sama juga dengan pola struktur pada bahasa Indonesia yang mana kata kerjanya tidak membutuhkan pelengkap. Untuk jenis kalimat ini dapat ditunjukkan dari salah satu kalimat pada data KTP-81 berikut.

\footnotetext{
Nganak latean dakahai kak?

$\begin{array}{lll}\mathrm{S} & \mathrm{P} & \mathrm{K}\end{array}$

(Kamu mau latihan tidak hari ini?)
}

Dari contoh data KTP-81 dengan jenis kalimat intransitif tersebut, memiliki pola struktur fungsi S,P,K. Pola struktur kalimat ini juga sama halnya dengan pola S,P yang 
mana P sebagai kata kerja dalam kalimat intransitif yang tidak membutuhkan pelengkap dan hanya membutuhkan K. Akan tetapi, unsur pelengkap dalam kalimat dengan wacana lisan ini sebenarnya dijelaskan pada kalimat-kalimat sebelumnya, misalnya dalam kalimat tersebut yang dimaksud latihan adalah latihan voli yang ini dapat dilihat pada kalimat sebelumnya. Untuk itu, unsur pelengkap dalam kalimat ini tidak membutuhkan pelengkap secara langsung.

Struktur kalimat intransitif dengan pola struktur fungsi P,K juga terdapat dalam wacana lisan bahasa Sindang. Struktur kalimat dengan pola ini disebut dengan kalimat minor yang mana fungsi $\mathrm{S}$ disenyapkan secara tersirat karena dalam bentuk wacana lisan. Contoh kalimat intransitif dengan pola struktur fungsi P,K pada data KTP-117, sebagai berikut.

Ade,gok gudang barang bekas.

$$
\text { (Ada, sekarang di gudang barang bekas.) }
$$

Dari data KTP-117 di atas, dapat kita ketahui bahwa kalimat tersebut merupakan kalimat minor yang S-nya dilesapkan dan tersirat dan yang dimaksud S adalah Suami Bibi Yam. Apabila ditulis lengkap maka kalimat tersebut menjadi:

Laki Bik Yam gok adedi gudang barang bekas.

S P K

(Suami Bibi Yam sekarang ada di gudang barang bekas.)

Struktur kalimat intransitif dengan pola struktur fungsi P,S juga terdapat dalam wacana lisan bahasa Sindang. Struktur kalimat dengan pola ini sungguh jarang kita temui dalam bahasa tulis ilmiah, tetapi dalam wacana lisan sering terjadi khususnya pada bahasa Sindang. Contoh kalimat intransitif dengan pola struktur P,S dapat dilihat pada data KTP-128 berikut.

Ape lah bedu betanakBik?"

$\mathrm{P} \quad \mathrm{S}$

(Apa sudah selesai masak Bibi?) 
Dari kalimat tersebut, dapat dijelaskan bahwa kalimat intransitif dapat berpola dengan struktur fungsi P, S dan idealnya berpola S,P. Akan tetapi, dalam wacana lisan, yang terpenting adalah bahasa yang bersifat komunikatif yaitu pesan yang disampaikan dapat dipahami oleh pendengar. Dengan pola P,S atau S,P memiliki makna pesan yang sama. Pada data KTP-128 tersebut, fungsi S juga berupa bentuk nomina vokatif yang berfungsi memberikan makna sapaan pada seorang Bibi sehingga kalimat tersebut menjadi lebih santun.

Struktur kalimat intransitif dengan pola struktur fungsi $\mathrm{P}$ juga terdapat dalam wacana lisan bahasa Sindang. Struktur kalimat dengan pola ini juga terdapat dalam bahasa Indonesia dan dinamakan kalimat minor yang fungsi S-nya ada, tetapi dilesapkan karena pendengar sudah memahami $\mathrm{S}$ pada komunikasi lisan secara langsung. Berikut salah satu contoh kalimat intransitif dengan pola struktur fungsi $\mathrm{P}$ khususnya pada data KTP-147.

Ao, dem aso-aso be ye!

(Iya, sudah pelan-pelan saja ya!)

Dari contoh data KTP-147 tersebut dapat diketahui bahwa kalimat tersebut berupa kalimat transitif yang berpola dengan struktur fungsi $\mathrm{P}$ dengan dilesapkan fungsi $\mathrm{S}$ dan diawali dengan kata persetujuan Iya dan diakhiri kata penekanan ya. Kalimat tersebut juga disebut kalimat minor yang mana $\mathrm{S}$ dalam kalimat tersebut apabila dilihat dari kalimat sebelumnya adalah Mia. Apabila kalimat tersebut menjadi kalimat dengan pola S,P menjadi Mia aso-aso be ye!

Kalimat intransitif dengan pola struktur fungsi S,P,S juga terdapat dalam wacana lisan bahasa Sindang. Struktur kalimat dengan pola ini sungguh unik karena fungsi Snya dipisah oleh fungsi $\mathrm{P}$ dan sebenarnya fungsi S-nya hanya satu. Contoh kalimat 
intransitif dengan pola struktur fungsi S,P,S dapat ditunjukkan pada data KTP-110 berikut.

Mujo Bik, anak ngagese hola peyang kecik hali tu.

Vokatif $S \quad P \quad S$

(Bagaimana Bik, anak bibi masih sekolah apa yang bungsu itu?)

Dari data KTP-110 di atas, dapat kita pahami bahwa kalimat tanya tersebut termasuk pada kalimat intransitif dengan pola struktur kalimat dengan fungsi S,P,S. Dalam kalimat ini, fungsi S sebenarnya hanya satu yaitu Anak nga yang kecik hali tu (Anak bibi yang bungsu itu) sehingga bila digabung kedua $\mathrm{S}$ tersebut, kalimatnya menjadi Mujo Bik, Anak nga yang kecik hali tu gese hola pe? (Bagaimana Bik, anak bibi yang bungsu itu masih sekolah apa? Kalimat transitif ini juga disebut kalimat tanya yang tidak memiliki objek dan tidak membutuhkan pelengkap yang di awali dengan kalimat tanya bagaimana (mujo) dan diikuti oleh nomina vokatif Bik (Bibi) sehingga kalimat menjadi lebih santun.

Kemudian, dalam bahasa Sindang di Kota Lubuklinggau untuk jenis kalimat intransitif dengan pola S,P,Pel. sebanyak 4 kalimat atau 5,1\% dari seluruh data penelitian. Berikut contoh kalimat intransitif dengan pola struktur fungsi S,P,Pel. khususnya pada data KTP-69.

“Oy Li $\frac{\text { kitekak nak betandengmaen voli. }}{\text { Vokatif }}$ S

(Oi Li, kita mau bertanding permainanvolly.)

Dari contoh kalimat intransitif dengan pola S,P,Pel. Memberikan informasi bahwa kalimat tersebut mengharuskan kehadiran pelengkap untuk menjelaskan kata kerja pada fungsi P. Apabila kalimat tersebut tidak diberikan Pelengkap, maka kalimat tersebut belum berterima atau belum jelas. Kalimat tersebut diawali dengan unsur 
nomina vokatif yang berfungsi sebagai kata sapaan yang juga sebenarnya bagian dari unsur Ssehingga kalimat intransitif menjadi lebih santun.

Kehadiran fungsi pelengkap yang wajib dalam kalimat intransitif sesuai dengan ciri-ciri fungsi pelengkap sebagai berikut: (1) dapat berkategori nomina atau frasa nominal, adjektiva atau frasa adjektival, verba atau frasa verbal, dan numeral atau frasa numeral; (2) pelengkap terletak di belakang $\mathrm{P}$ berkategori verba semitransitif, atau dwitransitif; (3)pelengkap yang terdapat dalam kalimat yang berpredikat verba dwitransitif tidak dapat menjadi S kalau kalimat dipasifkan. Selain itu, pelengkap yang terdapat pada kalimat yang berpredikat verba semitransitif tidak dapat dijadikan $\mathrm{S}$ karena kalimatnya tidak dapat dijadikan bentuk pasif; (4) pelengkap tidak dapat diganti dengan -nya; dan (5) pelengkapdapat didahului preposisi atau kata depan.

Dalam bahasa Sindang di Kota Lubuklinggau juga terdapat jenis kalimat tunggal berpredikat adjektival yang digunakan oleh masyarakat penuturnya khususnya pada percakapan wacana lisan. Kalimat tunggal berpredikat adjektival ini hanya sedikit digunakan dalam kegiatan komunikasi sehari-hari yaitu hanya ditemukan 4 kalimat atau 5,1\% dari seluruh data yang diteliti. Ditinjau dari struktur kalimat berdasarkan fungsi kalimat tunggal berpredikat adjektival memiliki dua bentuk struktur fungsi yaitu berstruktur K,S,P dan P,S. Untuk lebih jelasnya, dapat kita tunjukkan dengan contoh kalimat pada data KTP-119 berikut.

\footnotetext{
Men belek lah petang ye lah royo le!"

K S P

(Kalu pulang sudah sore dia capek juga kan!)
}

Dari contoh kalimat pada data KTP-119 di atas, kita dapat memahami bahwa struktur fungsi kalimat tunggal berpredikat adjektival (kata sifat/keadaan) royo/capek ini dapat berposisi di depan $\mathrm{S}$ dan di awal dengan fungsi K. Kata royo/capek dalam 
kalimat tersebut memiliki sebagian ciri-ciri yang disebutkan oleh Muslich (2010:97) yaitu: dapat diberi keterangan pembanding (lebih, kurang, paling); dapat diberi keterangan penguat (sangat, amat, benar, sekali, dan terlalu); dapat diberi kata ingkar tidak; dapat diulang dengan awalan se- dan akhiran -nya; pada kata-kata tertentu dapat bercirikan akhiran -ar, (w)i, -iah, -if, -al, dan -ik; umumnya berada di belakang kata benda yang diterangkan, baik yang berkonstruksi nomina + adjektiva (mobil tua), nomina + yang + adjektiva (mobil yang tua), maupun sebagai predikat dalam kalimat (mobil itu tua/mobilnya tua).

Kemudian, kalimat tunggal berpredikat adjektival dengan struktur fungsi P,S dapat dipahami dari data KTP-140 berikut.

Ao, dang angat nya kak Bik.

$\mathrm{P} \quad \mathrm{S}$

(Iya, sedang panas sekali Bik.)

Dari data kalimat KTP-140, dapat kita pahami bahwa dalam bahasa Sindang terdapat juga kalimat tunggal berpredikat adjektival yang berfungsi sebagai $\mathrm{P}$ dan posisinya secara langsung di belakang $\mathrm{S}$. Hal ini menunjukkan bahwa $\mathrm{P}$ dengan jenis adjektival ini sering muncul ketika memiliki struktur hanya dua fungsi, yaitu fungsi S,P dan P,S yang posisinya bisa secara langsung di depan S dan di belakang $\mathrm{S}$.

Dalam bahasa Sindang di Kota Lubukliggau juga terdapat kalimat tunggal berpredikat nominal yang mana dari data percakapan wacana lisan, hanya terdapat 1 kalimat atau 1,3\% dari seluruh data yang diteliti. Kalimat tunggal berpredikat nominal tersebut memiliki struktur kalimat dengan fungsi S,P. Contoh kalimat tersebut khususnya pada data KTP-115, sebagai berikut.

Men name homi kuSakban?

$\mathrm{S} \quad \mathrm{P}$

(Kalau nama suamiku Sakban) 
Dari kalimat KTP-115 di atas, menunjukkan bahwa fungsi $\mathrm{P}$ bukan saja berbentuk kata kerja (verba), tetapi dapat berbentuk kata benda (nomina). Akan tetapi, kalimat tunggal berpredikat nominal ini memang jarang digunakan oleh penutur bahasa Sindang di Kota Lubuklinggau. Hal ini bisa disebabkan oleh fungsi $\mathrm{P}$ berbentuk nomina hanya berfungsi menjelaskan $\mathrm{S}$ secara langsung dalam bentuk $\mathrm{P}$, tanpa diikuti oleh fungsi yang lain.

Berikutnya, kalimat tunggal berpredikat numeral juga digunakan oleh penutur bahasa Sindang di Kota Lubuklinggau khususnya dalam wacana lisan sehari-hari. Kalimat tunggal berpredikat numeral ini terdapat 8 kalimat atau $10 \%$ dari seluruh data yang diteliti. Kemudian, apabila ditinjau berdasarkan fungsi, kalimat tunggal berpredikat numeral tersebut memiliki dua struktur fungsi $\mathrm{S}, \mathrm{P}$ danP,S. Hal ini menunjukkan bahwa unsur $\mathrm{P}$ dapat diposisikan di depan $\mathrm{S}$ atau ditempatkan di belakang S. Kalimat tunggal berpredikat numeral ini lebih banyak berstruktur fungsi S,P dibandingkan dengan struktur fungsi P,S. Untuk lebih jelasnya berikut contoh kalimat tunggal berpredikat numeral dengan pola struktur kalimat dengan fungsi S,P, khususnya pada data KTP-103.

$\frac{\text { Anak kuade } 6 \text { ikok, } 4 \text { tine } 2 \text { lanang. }}{\mathrm{S}}$

(Anak bibik ada 6 orang, 4 perempuan 2 Laki-laki.)

Kalimat di atas, termasuk dalam kalimat tunggal berpredikat numeral karena fungsi P menunjukkan bilangan atau jumlah. Hal ini juga memberikan informasi bahwa fungsi S bukan saja berbentuk kata kerja (verba), tetapi dapat berbentuk kata bilangan (numeral). Dengan demikian, fungsi $\mathrm{P}$ berbentuk numeral dalam bahasa Sindang berfungsi menjelaskan jumlah fungsi S. Kemudian, untuk kalimat tunggal berpredikat 
numeral dengan struktur fungsi P,S juga ada dalam bahasa Sindang, berikut contohnya pada data KTP-04.

BenyakRa. ( Banyak Ra)

$\mathrm{P} \quad \mathrm{S}$ ( Banyak Ra)

Dari kalimat pada data KTP-04, dapat kita pahami bahwa kalimat tunggal berpredikat numeral juga bisa berstruktur fungsi P,S. Hal ini menunjukkan bahwa kata benyak yang berfungsi $\mathrm{P}$ sebagai kata bilangan (numeral) merupakan penjelasan dari kata $\mathrm{Ra}$ (penutur) sebagai kata benda(nomina) yang juga merangkapmenjadi nomina vokatif. Dengan demikian, fungsi P sebagai penjelasan dari fungsi S dapat diletakkan di belakang fungsi S, walaupun struktur fungsi P,S sangat sedikit digunakan oleh penutur dibandingkan dengan struktur fungsi S,P yang lebih dominan. Hal ini dikarenakan fungsi $\mathrm{S}, \mathrm{P}$ lebih bisa memberikan penjelasanatau pemahaman yang baik terhadap pendengar atau mitra tuturnya.

Dalam bahasa Sindang di Kota Lubuklinggau, penuturnya juga menggunakan kalimat tunggal berpredikat frase preposisional.Dari data percakapan wacana lisan bahasa Sindang di Kota Lubuklinggau hanya ditemukan kalimat tunggal berpredikat frase preposisionalberjumlah 1 kalimat atau $1,3 \%$ dari seluruh data yang diteliti. Sedangkan apabila kita lihat kalimat tunggal berpredikat frase preposisional ditinjau dari struktur kalimat berdasarkan fungsi memiliki struktur fungsi S,P,Vokatif. Untuk lebih jelasnya dapat ditunjukkan pada data KTP-146 berikut.

Yamma nenekkuBik.

S P Pokatif

(Yam ke rumah nenekku Bik.)

Dari contoh data KTP-146 di atas, dapat memberikan informasi bahwa fungsi P bukan hanya berbentuk verba, adjektival nomina, numeral, preposisional, tetapi bisa juga berbentuk preposisional atau kata depan. Dalam wacana lisan, biasanya fungsi $\mathrm{P}$ 
diakhiri unsur nomina vokatif atau di awal kalimat sebelum fungsi $\mathrm{S}$ sebagai sapaan kepada mitra tuturnya sehingga kalimat tersebut menjadi lebih komunikatif dan santun.

Jenis kalimat tunggal yang terakhir yang dimiliki bahasa Sindang di Kota Lubuklinggau yaitu kalimat tunggal berpredikat adverbial (kata keterangan/waktu).Jenis kalimat ini sungguh sangat langka dijumpai dalam beberapa bahasa termasuk dalam bahasa Indonesia. Untuk kalimat tunggal berpredikat adverbia dari data percakapan wacana lisan bahasa Sindang di Kota Lubuklinggau hanya 2 kalimat atau 2,6\% dari seluruh data yang diteliti. Kemudian, kalimat tunggal berpredikat adverbia dari data penelitian ditinjau dari struktur kalimat berdasarkan fungsi memiliki struktur fungsi S,P. Untuk lebih jelasnya dapat ditunjukkan pada data KTP-20 berikut.

Kalu kawo tutaonan.

S P

(Kalau kopi itu tahunan.)

Dari contoh kalimat di atas, dapat dijelaskan bahwa kalimat tersebut berbentuk kalimat tunggal berpredikat adverbial atau kata keterangan waktu. Hal ini ditunjukkan dengan kata tahunan yang bermakna waktu panen tanaman kopiadalah setiap tahun. Walaupun adverbial biasanya berfungsi dalam kalimat yang utuh berupa fungsi $\mathrm{K}$, tetapi kenyataannya dapat berbentuk fungsi P yang posisinya langsung di depan S.

Dengan demikian, dari beberapa jenis kalimat di atas dapat disimpulkan bahwa fungsi $\mathrm{P}$ (predikat) sebagai fungsi utama dalam kalimat tunggal dapat berupa verbal, adjektival, nominal, numeral, preposisional, dan adverbial. Dengan hadirnya variasi fungsi dalam kalimat, lahirlah berbagai jenis struktur kalimat tunggal khususnya dalam bahasa Sindang di Kota Lubuklinggau berupa: (1) kalimat tunggal berpredikat verbal yang terdiri atas kalimat intransitif dan kalimat tungggal ekatransitif; kalimat tunggal berpredikat adjektival, kalimat tunggal berpredikat nominal, kalimat tunggal berpredikat 
numeral, kalimat tunggal berpredikat preposisional, dan kalimat tunggal berpredikat adverbial.

Kemudian, sebagian besar kalimat tunggal berpredikat verbal khususnya jenis kalimat tunggal intransitif dengan struktur fungsi $\mathrm{S}, \mathrm{P}$ dan $\mathrm{S}, \mathrm{P}, \mathrm{K}$ paling banyak digunakan penutur bahasa Sindang di Kota Lubuklinggau dalam wacana lisan seharihari. Untuk jenis kalimat tunggal berpredikat verbal pada jenis kalimat dwitransitif dan intransitif belum ditemukan dalam data penelitian. Hal ini merupakan keterbatasan penelitiannya ini karena data yang diambil hanya dibatasi pada wacana lisan bahasa Sindang yang digunakan oleh masyarakat penutur dalam konteks keluarga dan bertetangga di Kelurahan Air Kuti Kecamatan Lubuklinggau Timur I dan Kayu Arah Kecamatan Lubuklinggau Barat, Kota LubuklinggauProvinsi Sumatera Selatan. Dengan informan penelitian hanya dua orang dari masing-masing kelurahan yang menjadi konteks masyarakat penutur bahasa Sindang.

\section{KESIMPULAN}

Dari hasil penelitian ini dapat disimpulkan bahwastruktur kalimat tunggal bahasa Sindang di Kota Lubuklinggau berbentuk kalimat tunggal berpredikat verbal yang terdiri atas kalimat intransitif dan kalimat tungggal ekatransitif; kalimat tunggal berpredikat adjektival, kalimat tunggal berpredikat nominal, kalimat tunggal berpredikat numeral, kalimat tunggal berpredikat preposisional, dan kalimat tunggal berpredikat adverbial. Sebagian besar kalimat tunggal berpredikat verbal pada bahasa Sindang lebih banyak digunakan oleh masyarakat penuturnya yaitu kalimat intransitif dengan 62 kalimat atau $79,5 \%$. Kalimat bahasa Sindang ditinjau dari segi fungsi untuk jenis kalimat intransitif memiliki struktur fungsi: 1). S,P; 2). K,S,P; 3). S,P,Vokatif; 4). S,P,K; 5). P,K; 6). P,S; 7). P; 8). S,P,S, dan 9). S,P,Pel. Jenis kalimat ekatransitif 
memiliki struktur fungsi: 1). K,S,P,O,K; 2). S,P,O,Vokatif; 3). P,O,K; 4). P,O; 5). $\mathrm{P}, \mathrm{O}, \mathrm{K}, \mathrm{S} ;$ 6). S,P,O; dan 7). P,O,S. Kalimat tunggal berpredikat adjektival memiliki struktur fungsi yaitu berstruktur K,S,P dan P,S. Kalimat tunggal berpredikat nominal memiliki struktur fungsi S,P. Kalimat tunggal berpredikat numeral memiliki struktur fungsi P,S dan S,P. Kalimat tunggal berpredikat frase preposisional memiliki struktur fungsi S,P,Vokatif. Kemudian, kalimat tunggal berpredikat adverbia memiliki struktur fungsi S,P. Struktur kalimat tunggal bahasa Sindang memberikan pengaruh positif terhadap pembelajaran bahasa Indonesia penutur asli bahasa tersebut.

\section{UCAPAN TERIMA KASIH}

Terima kasih kepada berbagai pihak yang menduukung pelaksanaan penelitian ini.

\section{DAFTAR PUSTAKA}

Badudu, J.S. (1998). Ilmu bahasa lapangan. Yogyakarta: Kanisius.

Chaer, A. (2007). Linguistik umum. Jakarta: Rineka Cipta.

Djajasudarma, T. F.. (2010). Metode linguistik: Ancangan metode penelitian dan kajian. Bandung: PT Refika Aditama.

Dardjowidjojo, S. (2010). Psikolingustik: Pengantar pemahaman bahasa manusia. Jakarta: Yayasan Obor Indonesia.

Kesuma, T. M. J. (2007). Pengantar Metode Penelitian Bahasa. Yogyakarta: CV Karyono.

Muslich, M. (2010). Garis-garis besar tatabahasa baku bahasa Indonesia. Bandung: Refika Aditama.

Parera, J.D. (2009). Dasar-dasar analisis sintaksis. Jakarta: Erlangga.

Putrayasa, I. B. (2007). Analisis kalimat (fungsi, kategori, dan peran). Bandung: PT Refika Aditama.

Ramlan, M. (2005). Ilmu bahasa Indonesia: Sintaksis. Yogyakarta: CV Karyono. 
Sudaryanto. (1993). Metode dan aneka analisis bahasa. Yogyakarta: Duta Wacana UP.

Suwandi. (1996). Kamus bahasa sindang. Lubuklinggau: STKIP-PGRI Lubuklinggau.

Verhaar, J.M.W.(1997). Asas-asas linguistik umum. Yogyakarta: Gadjah Mada University Press.

Verhaar, J.M.W. (2010). Asas-Asas linguistik umum. Yogyakarta: Gadjah Mada University Press.

Wijana, I Dewa Putu. (2011). Berkenalan dengan linguistik. Yokyakarta: A Com Advertising Yogyakarta.

Wikipedia. (2014). Suku lembak. http://id.wikipedia.org/wiki/Suku_Lembak. Diakses 2 Februari 2015. 